\title{
EKSTRAK BUAH NANAS UNTUK KESEHATAN WAJAH
}

\author{
*Reza Dahlia Putri \\ 17035038 \\ Fakultas Matematika Dan Ilmu Pengetahuan Alam \\ Universitas Negeri Padang \\ Email: rezadahliaputri09@gmail.com
}

\begin{abstract}
Abstrak
Studi ini bertujuan untuk mengetahui manfaat masker alami dari ekstrak buah nanas untuk kesehatan wajah. [1-10] Metode yang dilakukan dengan pembuatan ekstrak dan uji aktivitas katalis secara langsung. Tahap pertama yang dilakukan dengan pembuatan ekstrak dari buah nanas.[11-15] Uji aktivitas langsung dilakukan dengan bervariasi, yaitu sekali sehari selama seminggu. Hasil eksperimen membuktikan bahwa masker dari ekstrak buah nanas mampu mencerahkan kulit wajah, membersihkan dari kotoran serta memudarkan bekas jerawat.[15-20] Kondisi optimum ekstraksi tercapai pada waktu 30 hari. Hasil yang baik ini diduga karena aktivitas katalis ekstrak buah nanas terhadap kulit.[21-30]
\end{abstract}

Kata kunci : katalis, nanas, masker, ekstrak

\section{PENDAHULUAN}

\section{Latar Belakang}

Wajah yang bersih, sehat dan cerah tanpa jerawat tentu jadi impian sebagian besar wanita.Namun untuk hasil yang sangat memuaskan membutuhkan biaya yang mahal menjadi kendalanya. Untuk itu saya melakukan penelitian ini menggunakan ekstrak buah nanas untuk dijadikan masker wajah dengan memanfaatkan aktivitas katalis yang dilakukan oleh buah nanas secara reaksi kimia.[31-40]

\section{Landasan Teori}


Reaksi kimia adalah suatu reaksi yang memerlukan pereaksi yang menghasilkan produk baru dengan katalis sebagai pemicu mempercepat reaksi.[41-50] Buah nanas merupakan salah satu buah tropis yang disukai banyak orang. [51-55] Selain rasanya yang lezat, buah nanas juga memiliki beragam kandungan dan manfaat didalamnya. Mendapatkan manfaat buah nanas tidak selalu diperoleh dengan mengonsumsi lansung. Namun juga dijadikan masker yang ditempelkan pada kulit.[56-65]

Buah nanas merupakan salah satu solusi terbaik untuk perawatan kulit yang dapat menghasilkan rona kulit wajah yang cerah dan sehat. Nanas mengandung asam alpha hydroxyl yang berguna untuk mengangkat sel kulit mati, bisa juga digunakan untuk mencegah penuaan dini dan juga mengandung vitamin $\mathrm{C}$ yang dapat menyembuhkan peradangan pada kulit dan digunakan juga sebagai pencerah kulit.[66-75]

Nanas juga mengandung vitamin A yang dapat mengurangi resiko peradangan pada kulit dan juga berperan sebagai anti bakteri dan anti jamur. Nanas adalah sumber anti oksidan terbaik dalam bentuk vitamin $\mathrm{C}$ mendorong naiknya kekebalan tubuh denga mencegah radikal bebas.[76-85]

\section{METODE PENELITIAN}

\section{Alat Dan Bahan}

Peralatan dan bahan yang digunakan dalam penelitian studi kinetika ekstrak buah nenas terhadap kesehatan wajah adalah

Alat :

1. Pisau

2. Tissu

3. Blender

4. Mangkuk

5. Kamera Hp Samsung J2 Prime

Bahan :

1. Nenas 
2. Air

\section{Prosedur Kerja}

a. Penyiapan Bahan

Sampel diambil dari toko buah . Sampel diambil sebanyak 1 buah nenas

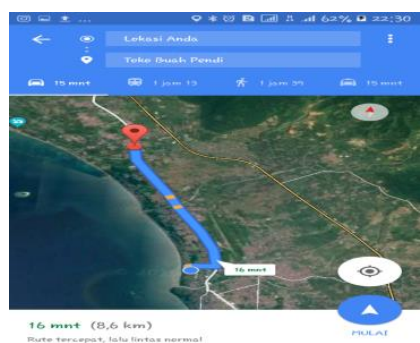

Ss lokasi

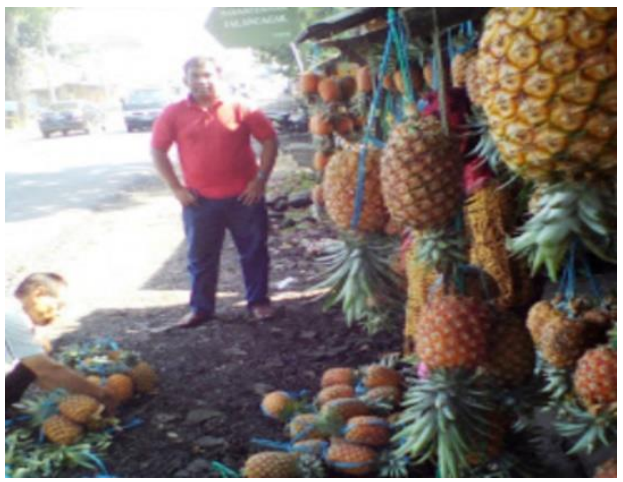

Foto buah

belah nanas menjadi dua bagian 


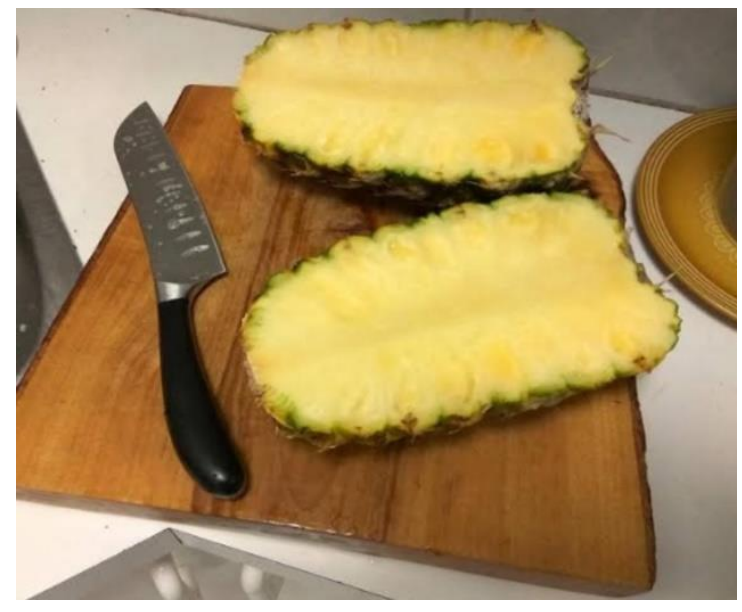

Sampel terlebih dahulu dicuci dulu dengan bersih

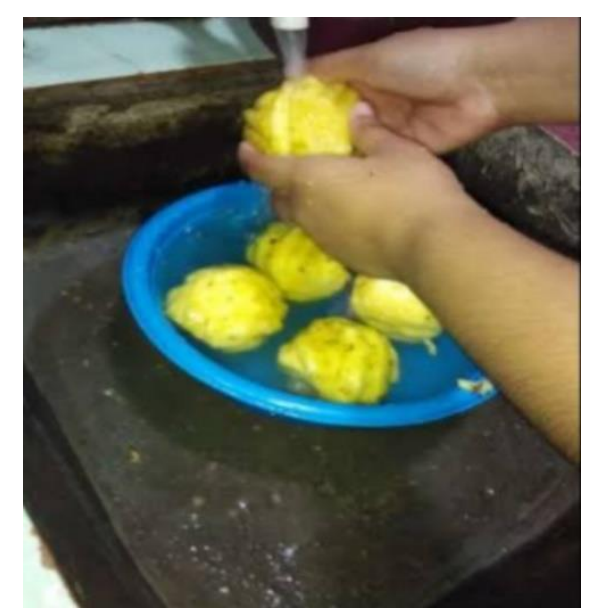

b. Pembuatan ekstrak

Sampel di ekstrak dengan serutan sebanyak setengah dari 1 buah nenas 


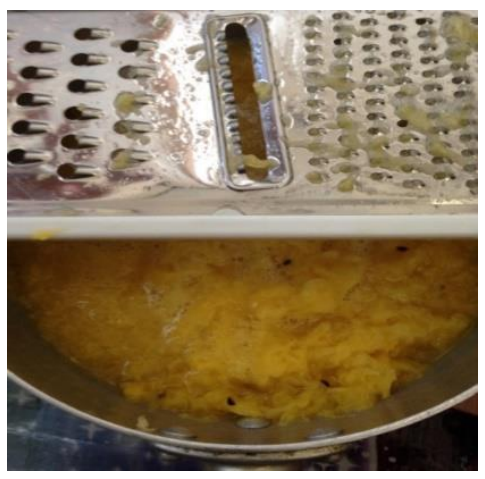

Kemudian sampel diperas. Air perasan dipisahkan dengan ampasnya.

Ambil ampasnya kemudian tambahkan madu secukupnya , kemudian campurkan keduanya dengan cara pengadukan rata.

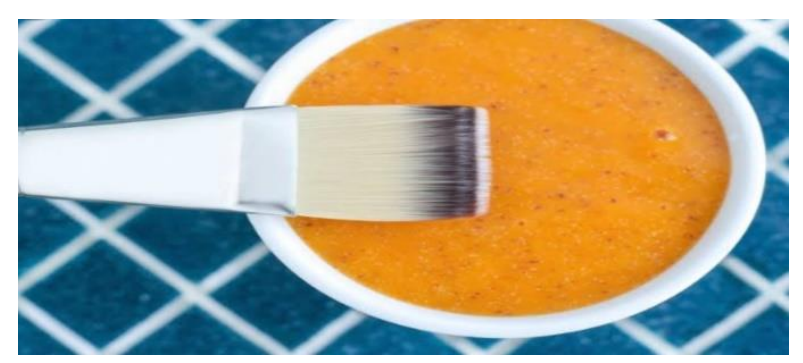

\section{Pengujian}

Masker yang telah jadi diuji cobakan dengan manusia sebanyak 1 orang Orang tersebut memakai marker 2x sehari selama seminggu

$>$ Masker dioleskan ke wajah dan didiamkan selama 20 menit

$>$ Kemuadian dibilas dengan air panas

> Hasil uji coba ditanyakan kepada orang yang dijadikan uji coba tadi. 
Skema metode penilitiannya dapat dilihat sebagai berikut :

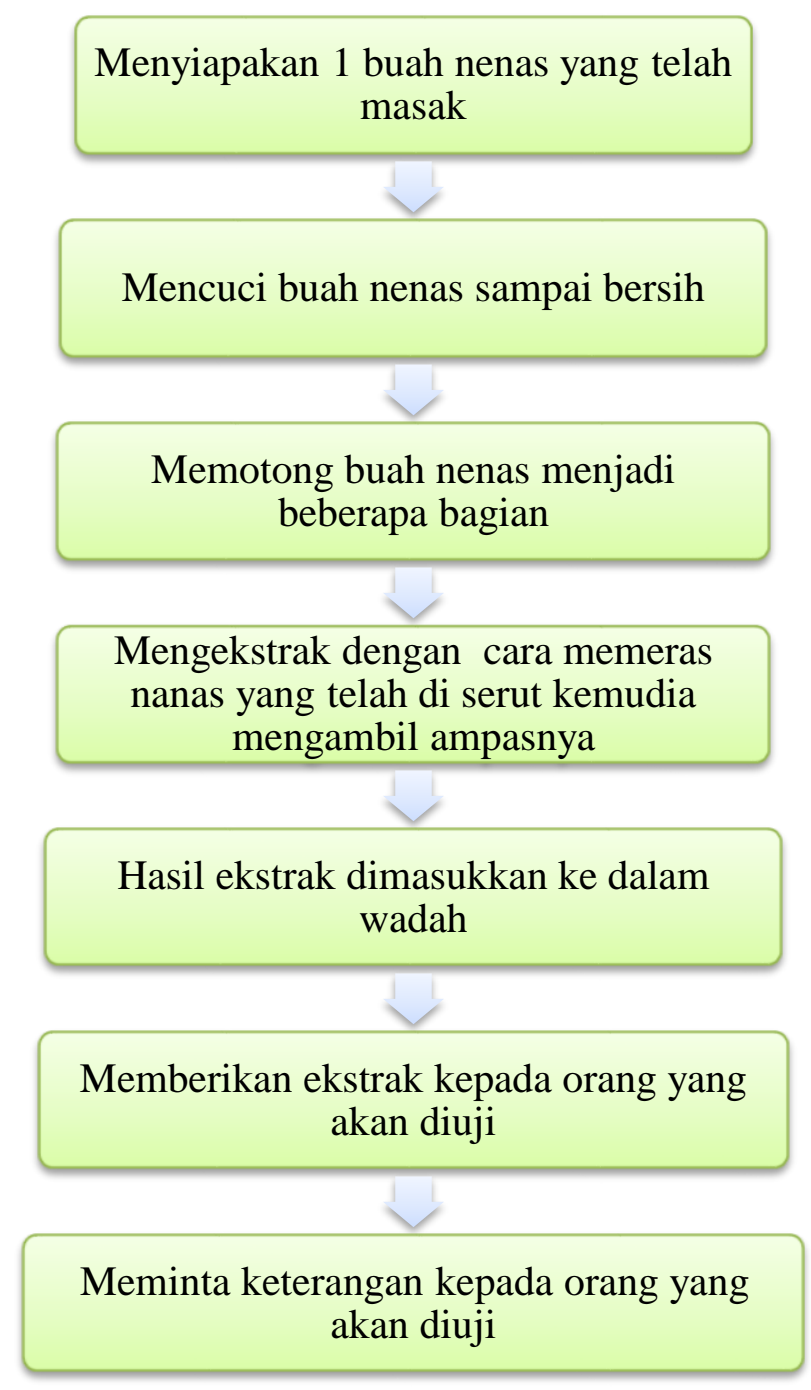

\section{Hasil Uji Coba}

Ekstrak nenas dari 1 buah nenas diperoleh sebanyak 500 gram . Pengujian terhadap ekstrak berhasil untuk menyehatkan kulit wajah. 


\section{PEMBAHASAN}

Buah nenas mengandung protein "bromelain" yang memiliki ptensi yang sama dengan "papain" yang dikemukan pada pepaya yang dapat mencerna protein sebesar 1000 kali beratnya, sehingga nanas bermanfaat sebagai pengahncur lemak. Dibuktikan pada penelitian ini bagaiamana peranan nenas sebagai katalis yang berguna untuk kesahatan wajah yang dibuah menjadi masker wajah. Kandungan enzim bromelain yang terdapat pada nenas memiliki beberapa manafaat salah satu diantaranya yaitu membantu pengangkatan sel kulit mati yang menumpuk sehingga membuat kulit tanpak lebih cerah.[86-100]

Bauh nanas yang dijadikan masker wajah mengandung sejumlah vitamin $\mathrm{c}$ yang cukup tinggi dan mampu merangsang produksi kologen dalam tubuh. Dimana buah nanas ini menghasilkan asam yang mampu melakukan pengelupassan sel kulit mati atau sel kulit yang telah menua.[101-120]

Pengaruh enzim bromelin berperan sebagai katalis yang semakin tinggi konsentrasinya akan mempengaruhi banyaknya substrat yang ditransdormasi. Waktu juga mempengaruhi kereaktifannya. Dimana kecepatan katalis enzim tersebut akan meningkat dengan lamannya waktu reaksi.[121-140] Dimana hal ini menjelaskan apabila pemakaian masker dengan waktu yang tepat akan memaksimalkan hasil yang dibuktikan dengan wajah yang sehat.[141-169]

\section{KESIMPULAN}

1. Dari setengah buah nanas yang telah masak didapati ekstraknya sebanyak 500 gram

2. masker dari ekstrak buah nanas terbukti mampu menyehatkan kulit wajah karena mengandung enzim bromelin

\section{REFERENSI}

[1] Zainul, R. (2018, August 16). Effect Of Temperature And Particle Motion Against The Ability Of Zno Semiconductor Photocatalyst In Humic Acid. Https://Doi.Org/10.31227/Osf.Io/Wnygb 
[2] Liza, Y. M., Yasin, R. C., Maidani, S. S., \& Zainul, R. (2018, October 9). Sol Gel : Principle And Technique (A Review). Https://Doi.Org/10.31227/Osf.Io/2cuh8

[3] Febriani, S. S., Yolanda, T., Arianti, V. A., \& Zainul, R. (2018, October 12). A Review Solid Stated Principles And Methode. Https://Doi.Org/10.31227/Osf.Io/7us4x

[4] Dinata, A. A., Rosyadi, A. M., Hamid, S., \& Zainul, R. (2018, October 15). A Review Chemical Vapor Deposition : Process And Application. Https://Doi.Org/10.31227/Osf.Io/Yfeau

[5] Putri, D. F., Ritonga, H. M., Murdiati, V., \& Zainul, R. (2018, October 15). A Review What Is Hydrothermal ?. Https://Doi.Org/10.31227/Osf.Io/Dm56c

[6] Alfionita, T., \& Zainul, R. (2019, January 29). Calcium Chloride (Cacl2) : Characteristics And Molecular Interaction In Solution. Https://Doi.Org/10.31227/Osf.Io/M37xj

[7] Yuliani, F., \& Zainul, R. (2018, November 13). Analisis Termodinamika Molekul Magnesium Sulphate (Mgso4). Https://Doi.Org/10.31227/Osf.Io/Uxz4y

[8] Zainul, R., Alif, A., Aziz, H., Arief, S., \& S. (2018, August 16). Photoelectrosplitting Water Mechanism At Carbon Electrode Surface Using Indoor Lights. Https://Doi.Org/10.31227/Osf.Io/Vcxq8

[9] Chaidir, Z., Zainul, R., Nurakhbari, D., \& Salim, M. (2018, July 29). Optimization Of Spirulina Platensis Culture For Antioxidant Production. Https://Doi.Org/10.17605/Osf.Io/Fd6e4 
[10] Alfionita, T., \& Zainul, R. (2019, January 29). Calcium Chloride (Cacl2) : Characteristics And Molecular Interaction In Solution. Https://Doi.Org/10.31227/Osf.Io/M37xj

[11] Yuliani, F., \& Zainul, R. (2018, November 13). Analisis Termodinamika Molekul Magnesium Sulphate (Mgso4). Https://Doi.Org/10.31227/Osf.Io/Uxz4y

[12] Zainul, R., Alif, A., Aziz, H., Arief, S., \& S. (2018, August 16). Photoelectrosplitting Water Mechanism At Carbon Electrode Surface Using Indoor Lights. Https://Doi.Org/10.31227/Osf.Io/Vcxq8

[13] Chaidir, Z., Zainul, R., Nurakhbari, D., \& Salim, M. (2018, July 29). Optimization Of Spirulina Platensis Culture For Antioxidant Production. Https://Doi.Org/10.17605/Osf.Io/Fd6e4

[14] Alfionita, T., \& Zainul, R. (2019, January 29). Calcium Chloride (Cacl2) : Characteristics And Molecular Interaction In Solution. Https://Doi.Org/10.31227/Osf.Io/M37xj

[15] Yuliani, F., \& Zainul, R. (2018, November 13). Analisis Termodinamika Molekul Magnesium Sulphate (Mgso4). Https://Doi.Org/10.31227/Osf.Io/Uxz4y

[16] Sari, M., \& Zainul, R. (2018, November 19). Kalium Dikromat (K2cr2o7) Spektroskopi Dan Transpor K2cr2o7. Https://Doi.Org/10.31227/Osf.Io/W92je

[17] Feronika, N. I., \& Zainul, R. (2018, November 19). Kalium Permanganat: Termodinamika Mengenai Transport Ionik Dalam Air. Https://Doi.Org/10.31227/Osf.Io/G6eyk

[18] Zainul, R. (2019, January 15). F. Https://Doi.Org/10.31227/Osf.Io/75pdj 
[19] Kristy, D. P., \& Zainul, R. (2019, February 3). Analisis Molekular Dan Transpor Ion Natrium Silikat. Https://Doi.Org/10.31227/Osf.Io/8ac4m

[20] Lubis, A. P., \& Zainul, R. (2018, November 5). Interaksi Molekuler Amonium Hidroksida. Https://Doi.Org/10.31227/Osf.Io/Jht3b

[21] Husna, H., \& Zainul, R. (2019, February 3). A Review : Aspek Termodinamika Lino3 Dalam Larutannya. Https://Doi.Org/10.31227/Osf.Io/45mbd

[22] Chaidir, Z., Fadjria, N., A., \& Zainul, R. (2018, August 11). Isolation And Molecular Identification Of Freshwater Microalgae In Maninjau Lake West Sumatera. Https://Doi.Org/10.31227/Osf.Io/Nbcuf

[23] Chaidir, Z., Fadjria, N., A., \& Zainul, R. (2018, August 11). Isolation And Molecular Identification Of Freshwater Microalgae In Maninjau Lake West Sumatera. Https://Doi.Org/10.31227/Osf.Io/Nbcuf

[24] Warlinda, Y. A., \& Zainul, R. (2019, January 29). Asam Posfat (H3po4): Ionic Transformation Of Phosphoric Acid In Aqueous Solution. Https://Doi.Org/10.31227/Osf.Io/S3y8v

[25] Yanti, C. F., \& Zainul, R. (2018, December 2). A Review Ba (Oh)2 : Transpor Ionik Pada Barium Hidroksida Di Dalam Air Dengan Konsep Termodinamika. Https://Doi.Org/10.31227/Osf.Io/Fsbq3

[26] Putri, G. E., Arief, S., Jamarun, N., Gusti, F. R., \& Zainul, R. (2018, December 10). Microstuctural Analysis And Optical Properties Of Nanocrystalline Cerium Oxides Synthesized By Precipitation Method. Https://Doi.Org/10.31227/Osf.Io/Qcz4y 
[27] Putri, G. E., Arief, S., Jamarun, N., Gusti, F. R., \& Zainul, R. (2018, December 10). Microstuctural Analysis And Optical Properties Of Nanocrystalline Cerium Oxides Synthesized By Precipitation Method. Https://Doi.Org/10.31227/Osf.Io/Qcz4y

[28] Zainul, R. (2018, December 24). Prototype Reaktor Deksagonal. Https://Doi.Org/10.31227/Osf.Io/D7wzk

[29] Shafitri, M., \& Zainul, R. (2019, February 3). Vanadium Pentaoksida (V2o5) : Termodinamika Molecular Dan Interaksi Ion Dalam Larutan. Https://Doi.Org/10.31227/Osf.Io/Jgmvd

[30] Jumalia, R., \& Zainul, R. (2019, February 3). Natrium Karbonat : Termodinamika Dan Transport Ion. Https://Doi.Org/10.31227/Osf.Io/Y2vq9

[31] Delvi, I. P., \& Zainul, R. (2019, February 3). Mercury (Ii) Nitrate (Hg (No3)2): Interaksi Molekul Dan Adsorpsi $\mathrm{Hg}$ Dengan Karbon Aktif. Https://Doi.Org/10.31227/Osf.Io/Eqyax

[32] Hakimi, A., \& Zainul, R. (2019, January 31). Asam Arsenat (H3aso4) : Analisis Molekular Dan Karakteristik Senyawa. Https://Doi.Org/10.31227/Osf.Io/E486z

[33] Rahmadhanty, S., \& Zainul, R. (2018, December 24). Design Of Humat Acid Solid Solution Reactor Through Phototransformation Of Copper Oxide (Cuo) Semiconductor Plate. Https://Doi.Org/10.31227/Osf.Io/Yhd9x

[34] Artika, P. I., \& Zainul, R. (2018, November 19). Potassium Bromide (Kbr): Transformasi Ionik Dan Sifat Temodinamika Dalam Larutan. Https://Doi.Org/10.31227/Osf.Io/A5hyz

[35] Sari, E. S. J., \& Zainul, R. (2019, January 31). Nitrogen Triflorida (Nf3) : Termodinamika Dan Transpor Elektron Nf3. Https://Doi.Org/10.31227/Osf.Io/3nzrh 
[36] H., Azhar, M., \& Zainul, R. (2018, September 19). The Effectiveness Of Structured Inquiry Based Module To Improve Mental Model Of Concept Mole. Https://Doi.Org/10.31227/Osf.Io/Ckjtb

[37] H., Azhar, M., \& Zainul, R. (2018, September 19). The Effectiveness Of Structured Inquiry Based Module To Improve Mental Model Of Concept Mole. Https://Doi.Org/10.31227/Osf.Io/Ckjtb

[38] Dwynda, I., \& Zainul, R. (2018, November 19). Boric Acid (H3 (Bo3): Recognize The Molecular Interactions In Solutions. Https://Doi.Org/10.31227/Osf.Io/6wead

[39] M., Sanjaya, H., \& Zainul, R. (2018, August 11). Characterization Of Napa Soil And Adsorption Of $\mathrm{Pb}$ (Ii) From Aqueous Solutions Using On Column Method. Https://Doi.Org/10.31227/Osf.Io/T8fh9

[40]Zainul, R. (2018, August 16). Determination Of The Half-Life And The Quantum Yield Of Zno Semiconductor Photocatalyst In Humic Acid. Https://Doi.Org/10.31227/Osf.Io/E8a9x

[41] Rizki Saputra, M. And Sumarmin, R. (2018) "Pengaruh Ekstrak Daun Sirih Merah (Piper Crocatum Ruiz \& Pav.) Terhadap Glukosa Darah Mencit (Mus Musculus L.) Jantan Yang Diinduksi Sukrosa", EKSAKTA: Berkala Ilmiah Bidang MIPA, 19(1), Pp. 43-55. Doi: 10.24036/Eksakta/Vol19-Iss1/124.

[42] Sari, A. (2017) "Potensi Antioksidan Alami Pada Ekstrak Daun Jamblang (Syzigium Cumini (L.) Skeels)", EKSAKTA: Berkala Ilmiah Bidang MIPA, 18(02), Pp. 107-112. Doi: 10.24036/Eksakta/Vol18-Iss02/61.

[43] Huda, N. (2017) "Pengaruh Ekstrak Sambiloto (Andrographis Paniculata Nees.) Terhadap Siklus Estrus Mencit (Mus Musculus L. Swiss Webster)”, EKSAKTA: 
Berkala Ilmiah Bidang MIPA, 18(02), Pp. 69-76. Doi: 10.24036/Eksakta/Vol18Iss02/55.

[44] Sumarmin, R. (2018) "Pengaruh Ekstrak Kulit Buah Manggis (Garcinia Mangostana

L.) Terhadap Histologis Pankreas Mencit (Mus Musculus L. Swiss Webster) Yang Diinduksi Sukrosa", EKSAKTA: Berkala Ilmiah Bidang MIPA, 19(1), Pp. 100-112. Doi: 10.24036/Eksakta/Vol19-Iss1/123.

[45] Dinata, M. And Soehardi, F. (2018) "Factor Analysis Of Physics Chemistry Waters That Affects Damage Safety Cliff On The Outskirts Of River Siak", EKSAKTA: Berkala Ilmiah Bidang MIPA, 19(2), Pp. 46-49. Doi: 10.24036/Eksakta/Vol19Iss $2 / 143$.

[46] Suryelita, S., Etika, S. B. And Kurnia, N. S. (2017) "Isolasi Dan Karakterisasi Senyawa Steroid Dari Daun Cemara Natal (Cupressus Funebris End1.)", EKSAKTA: Berkala Ilmiah Bidang MIPA, 18(01), Pp. 86-94. Doi: 10.24036/Eksakta/Vol18Iss01/23.

[47] Iryani, I., Iswendi, I. And Katrina, I. T. (2017) “Uji Aktivitas Anti Diabetes Mellitus Senyawa Metabolit Sekunder Fraksi Air Dari Beras Ketan Hitam ( Oryza Satival. Var Glutinosa) Pada Mencit Putih”, EKSAKTA: Berkala Ilmiah Bidang MIPA, 18(01), Pp. 54-60. Doi: 10.24036/Eksakta/Vol18-Iss01/17.

[48] Horiza, H., Azhar, M. And Efendi, J. (2017) "Ekstraksi Dan Karakterisasi Inulin Dari Umbi Dahlia (Dahlia Sp.L) Segar Dan Disimpan”, EKSAKTA: Berkala Ilmiah Bidang MIPA, 18(01), Pp. 31-39. Doi: 10.24036/Eksakta/Vol18-Iss01/14.

[49] Samah, S. (2017) "Karakterisasi Plastik Biodegradabel Dari Ldpe-G-Ma Dan Pati Tandan Kosong Sawit”, EKSAKTA: Berkala Ilmiah Bidang MIPA, 18(02), Pp. 30-38. Doi: 10.24036/Eksakta/Vol18-Iss02/48. 
[50] Saiya, A. (2017) “Analisis Residu Klorpirifos Dalam Sayuran Kubis Dengan Metode Hplc Di Beberapa Pasar Tradisional Di Sulawesi Utara”, EKSAKTA: Berkala Ilmiah Bidang MIPA, 18(02), Pp. 77-85. Doi: 10.24036/Eksakta/Vol18-Iss02/5

[51] Ningsih, S. K. (2017) "Sintesis Dan Karakterisasi Nanopartikel Zno Doped Cu2+ Melalui Metoda Sol-Gel”, EKSAKTA: Berkala Ilmiah Bidang MIPA, 18(02), Pp. 3951. Doi: 10.24036/Eksakta/Vol18-Iss02/51.

[52] Sanjaya, H. (2018) "Degradasi Metil Violet Menggunakan Katalis Zno-Tio2 Secara Fotosonolisis", EKSAKTA: Berkala Ilmiah Bidang MIPA, 19(1), Pp. 91-99. Doi: 10.24036/Eksakta/Vol19-Iss1/131.

[53] Prabowo, H. (2018) "Penyelidikan Kelayakan Kimia Dan Penyebaran Cadangan Pasir Besi Daerah Tiku Kabupaten Agam Untuk Bahan Baku Semen Pada PT. Semen Padang”, EKSAKTA: Berkala Ilmiah Bidang MIPA, 19(1), Pp. 39-42. Doi: 10.24036/Eksakta/Vol19-Iss1/121.

[54] Sanjaya, H. (2017) "Degradasi Methylene Blue Menggunakan Katalis Zno-PEG Dengan Metode Fotosonolisis", EKSAKTA: Berkala Ilmiah Bidang MIPA, 18(02), Pp. 21-29. Doi: 10.24036/Eksakta/Vol18-Iss02/45.

[55] Tutuarima, T. (2017) "Sifat Fisik Dan Kimia Marmalade Jeruk Kalamansi (Citrus Microcarpa) : Kajian Konsentrasi Pektin Dan Sukrosa Physical And Chemical Properties Of Marmalade Citrus Of Calamondin (Citrus Microcarpa) : Study Of Pectin And Sucrose Concentrations", EKSAKTA: Berkala Ilmiah Bidang MIPA, 18(02), Pp. 164-172. Doi: 10.24036/Eksakta/Vol18-Iss02/73.

[56] Azhar, M., Ahda, Y., Ihsanawati, I., Puspasari, F., Mawarni, S., Risa, B. And Natalia, D. (2017) "Skrining Bakteri Pendegradasi Inulin Dari Rizosfer Umbi Dahlia Menggunakan Inulin Umbi Dahlia”, EKSAKTA: Berkala Ilmiah Bidang MIPA, 18(02), Pp. 13-20. Doi: 10.24036/Eksakta/Vol18-Iss02/44. 
[57] Mulia, M. (2017) "Isolasi Kumarin Dari Kulit Buah Limau Sundai (Citrus Nobilis Lour)", EKSAKTA: Berkala Ilmiah Bidang MIPA, 18(02), Pp. 137-145. Doi: 10.24036/Eksakta/Vol18-Iss02/70.

[58] Putri, D., Anika, M. And Wahyuni, W. (2019) "Bioinformatics Study Genes Encoding Enzymes Involved In The Biosynthesis Of Carotenoids Line Cassava (Manihot Esculenta)", EKSAKTA: Berkala Ilmiah Bidang MIPA, 20(1), Pp. 10-16. Doi: 10.24036/Eksakta/Vol20-Iss1/161.

[59] Ruswandi, R. (2018) "Determination Of Fructose Content Resulted By Inulin Hydrolysis With DNS As Oxidizer”, EKSAKTA: Berkala Ilmiah Bidang MIPA, 19(1), Pp. 14-23. Doi: 10.24036/Eksakta/Vol19-Iss1/102.

[60] Hidayani, T. (2018) "Grafting Polipropilena Dengan Maleat Anhidrida Sebagai Pengikat Silang Dengan Inisiator Benzoil Peroksida", EKSAKTA: Berkala Ilmiah Bidang MIPA, 19(1), Pp. 56-62. Doi: 10.24036/Eksakta/Vol19-Iss1/127.

[61] Horiza, H. (2018) "The Influence Of The Use Of Activated Carbon Fibres Of The Cane Against The Drop In Salinity In The Well Dig In RT 003 RW 006 Village Cape Town Unggat Tanjungpinang Year 2017”, EKSAKTA: Berkala Ilmiah Bidang MIPA, 19(1), Pp. 1-6. Doi: 10.24036/Eksakta/Vol19-Iss1/97.

[62] Hidayat, D. (2018) “Analisis Respon Pengontrol On-Off Pada Kendali Umpan Balik Sistem Fisis Elektronik", EKSAKTA: Berkala Ilmiah Bidang MIPA, 19(1), Pp. 118124. Doi: 10.24036/Eksakta/Vol19-Iss1/119.

[63] Joebaedi, K. (2018) "Model Star(1;1) Pada Data Produktivitas Teh", EKSAKTA: Berkala Ilmiah Bidang MIPA, 19(1), Pp. 35-38. Doi: 10.24036/Eksakta/Vol19Iss $1 / 118$. 
[64] Hidayat, D. (2017) "Implementasi Pengontrol Pid Pada Model Fisis Elektronik", EKSAKTA: Berkala Ilmiah Bidang MIPA, 18(02), Pp. 178-185. Doi: 10.24036/Eksakta/Vol18-Iss02/75.

[65] Kurniawati, Y., Amalita, N. And Syafriandi, S. (2017) "Penerapan Importance Performance Analysis Dalam Menilai Kepuasaan Stakeholder Terhadap Kinerja Pkl Mahasiswa D3 Statistika", EKSAKTA: Berkala Ilmiah Bidang MIPA, 18(01), Pp. 111. Doi: 10.24036/Eksakta/Vol18-Iss01/4.

[66] Fati, N., Siregar, R. And Sujatmiko, S. (2019) “Addition Of Coleus Amboinicus, L Leaf's Extract In Ration To Percentage Of Carcass, Abdominal Fat, Liver And Heart Broiler", EKSAKTA: Berkala Ilmiah Bidang MIPA, 20(1), Pp. 1-9. Doi: 10.24036/Eksakta/Vol20-Iss1/157.

[67] Putri, D., Anika, M. And Wahyuni, W. (2019) "Bioinformatics Study Genes Encoding Enzymes Involved In The Biosynthesis Of Carotenoids Line Cassava (Manihot Esculenta)", EKSAKTA: Berkala Ilmiah Bidang MIPA, 20(1), Pp. 10-16. Doi: 10.24036/Eksakta/Vol20-Iss1/161.

[68] Suratno, T., Rarasati, N. And Z G. (2019) “Optimization Of Genetic Algorithm For Implementation Designing And Modeling In Academic Scheduling”, EKSAKTA: Berkala Ilmiah Bidang MIPA, 20(1), Pp. 17-24. Doi: 10.24036/Eksakta/Vol20Iss $1 / 166$.

[69] Ramalisa, Y., Febriyanti, A. And Multahadah, C. (2019) "Analysis Of Non Hierarchical Bomb For Collection Of Community Health Degrees In Jambi And Muaro Jambi City”, EKSAKTA: Berkala Ilmiah Bidang MIPA, 20(1), Pp. 25-34. Doi: 10.24036/Eksakta/Vol20-Iss1/167.

[70] Pasaribu, F., Mardia, A. And Sormin, C. (2019) "Ordinal Logistic Regression With An Application To Health Service Quality In Raden Mattaher Jambi Hospital", 
EKSAKTA: Berkala Ilmiah Bidang MIPA, 20(1), Pp. 35-40. Doi: 10.24036/Eksakta/Vol20-Iss1/168.

[71] Badrulfalah, B., Susanti, D., Joebaedi, K. And Kosasih, R. (2019) "Some Properties Of Green's Matrix Of Nonlinear Boundary Value Problem Of First Order Differential”, EKSAKTA: Berkala Ilmiah Bidang MIPA, 20(1), Pp. 41-47. Doi: 10.24036/Eksakta/Vol20-Iss1/173.

[72] Joebaedi, K., Susanti, D., Warwah, N., Parmikanti, K. And Badrulfalah, B. (2019) "Factors Affecting The Amount Of Investment Loans In Commercial Banks With The Application Of Linear Regression Analysis Methods", EKSAKTA: Berkala Ilmiah Bidang MIPA, 20(1), Pp. 48-54. Doi: 10.24036/Eksakta/Vol20-Iss1/172.

[73] Suhaemi, Z., Zulkarnaini, Z., Afrijon, A. And Jefri, P. (2019) "The Study Of African Leave (Vernonia Amygdalina) In For Improving The Quality Of Local Duck Meats Of West Sumatera", EKSAKTA: Berkala Ilmiah Bidang MIPA, 20(1), Pp. 55-59. Doi: 10.24036/Eksakta/Vol20-Iss1/174.

[74] Afnuhazi, R. (2019) "Bivariate Analysis On Autism Therapy Using Social Skills Training In SLB YPPA Padang”, EKSAKTA: Berkala Ilmiah Bidang MIPA, 20(1), Pp. 60-76. Doi: 10.24036/Eksakta/Vol20-Iss1/175.

[75] Dinata, M., Fitridawati, F. And Putri, L. (2019) "The Study Trees Potential For Forest In Universitas Lancang Kuning Pekanbaru”, EKSAKTA: Berkala Ilmiah Bidang MIPA, 20(1), Pp. 77-85. Doi: 10.24036/Eksakta/Vol20-Iss1/176.

[76] Syafei, N. (2019) "Events Of Corrosion Phenomena On Carbon Steel Pipes In Environment Of Sea Water And Ammonia Solutions Due To The Presence Of Sweet Gas”, EKSAKTA: Berkala Ilmiah Bidang MIPA, 20(1), Pp. 86-99. Doi: 10.24036/Eksakta/Vol20-Iss1/178. 
[77] Zainul, R. And Wardani, S. (2019) “The Hydrogen Generator Performance Of Sandwich Designed 4/4 Al-Cu Plates”, EKSAKTA: Berkala Ilmiah Bidang MIPA, 20(1), Pp. 100-104. Doi: 10.24036/Eksakta/Vol20-Iss1/177.

[78] Amir, H., Akmam, A., Bavitra, B. And Azhari, M. (2017) "Penentuan Kedalaman Batuan Dasar Menggunakan Metode Geolistrik Tahanan Jenis Dengan Membandingkan Konfigurasi Dipole-Dipole Dan Wenner Di Bukit Apit Puhun Kecamatan Guguk Panjang Kota Bukittinggi”, EKSAKTA: Berkala Ilmiah Bidang MIPA, 18(01), Pp. 19-30. Doi: 10.24036/Eksakta/Vol18-Iss01/13.

[79] Iskandar, I., Horiza, H. And Fauzi, N. (2017) "Efektivitas Bubuk Biji Pepaya (Carica Papaya Linnaeaus) Sebagai Larvasida Alami Terhadap Kematian Larva Aedes Aegypty Tahun 2015”, EKSAKTA: Berkala Ilmiah Bidang MIPA, 18(01), Pp. 12-18. Doi: 10.24036/Eksakta/Vol18-Iss01/12.

[80] Sumarmin, R., Yuniarti, E. And Razak, A. (2017) "Kualitas Sperma Ejakulat Pejantan Ayam Kukuak Balenggek Pada Pengandangan Tunggal Terisolasi (Ejaculated Sperm Quality Of Isolated Single Caging Of Balenggek Chickens)”, EKSAKTA: Berkala Ilmiah Bidang MIPA, 18(01), Pp. 40-45. Doi: 10.24036/Eksakta/Vol18-Iss01/15.

[81] Ramli, R., Jonuarti, R. And Hartono, A. (2017) “Analisis Struktur Nano Dari Lapisan Tipis Cobalt Ferrite Yang Dipreparasi Dengan Metode Sputtering”, EKSAKTA: Berkala Ilmiah Bidang MIPA, 18(01), Pp. 46-53. Doi: 10.24036/Eksakta/Vol18Iss01/16.

[82] Handayani, D. (2017) "Karakteristik Cendawan Dark Septate Endophyte (Dse) Pada Akar Tanaman Jagung Dan Padi”, EKSAKTA: Berkala Ilmiah Bidang MIPA, 18(01), Pp. 61-68. Doi: 10.24036/Eksakta/Vol18-Iss01/20. 
[83] Syafei, N. (2018) "Riset Material Analisa Fenomena Korosi Pelat Pipa Baja Karbon Api 5l-X65 Dalam Larutan 7900 Ml Air Laut Dan 100 Ml Amoniak Pada Kondisi Gas Co2 Dan H2s Jenuh Pada Suhu Ruang.”, EKSAKTA: Berkala Ilmiah Bidang MIPA, 19(1), Pp. 7-13. Doi: 10.24036/Eksakta/Vol19-Iss1/83.

[84] Santoso, B. (2018) "Identifikasi Akuifer Menggunakan Metode Geolistrik Resistivitas Di Daerah Bebandem, Karang Asem, Bali”, EKSAKTA: Berkala Ilmiah Bidang MIPA, 19(1), Pp. 24-34. Doi: 10.24036/Eksakta/Vol19-Iss1/101.

[85] Joebaedi, K. (2018) "Model Star(1;1) Pada Data Produktivitas Teh", EKSAKTA: Berkala Ilmiah Bidang MIPA, 19(1), Pp. 35-38. Doi: 10.24036/Eksakta/Vol19Iss $1 / 118$.

[86] Hidayani, T. (2018) "Grafting Polipropilena Dengan Maleat Anhidrida Sebagai Pengikat Silang Dengan Inisiator Benzoil Peroksida”, EKSAKTA: Berkala Ilmiah Bidang MIPA, 19(1), Pp. 56-62. Doi: 10.24036/Eksakta/Vol19-Iss1/127.

[87] Advinda, L. (2018) "Pertumbuhan Stek Horizontal Batang Jarak Pagar (Jatropha Curcas L.) Yang Diintroduksi Dengan Pseudomonad Fluoresen", EKSAKTA: Berkala Ilmiah Bidang MIPA, 19(1), Pp. 68-75. Doi: 10.24036/Eksakta/Vol19-Iss1/129.

[88] Hidayat, D. (2018) “Analisis Respon Pengontrol On-Off Pada Kendali Umpan Balik Sistem Fisis Elektronik”, EKSAKTA: Berkala Ilmiah Bidang MIPA, 19(1), Pp. 118124. Doi: 10.24036/Eksakta/Vol19-Iss1/119.

[89] Putri, D., Fifendy, M. And Putri, M. (2018) "Diversitas Bakteri Endofit Pada Daun Muda Dan Tua Tumbuhan Andaleh (Morus Macroura Miq.)”, EKSAKTA: Berkala Ilmiah Bidang MIPA, 19(1), Pp. 125-130. Doi: 10.24036/Eksakta/Vol19-Iss1/122.

[90] Syafei, N. (2018) "Riset Material Analisa Fenomena Korosi Pelat Pipa Baja Karbon Api 5l-X65 Dalam Larutan 7900 Ml Air Laut Dan 100 Ml Amoniak Pada Kondisi Gas 
Co2 Dan H2s Jenuh Pada Suhu Ruang.”, EKSAKTA: Berkala Ilmiah Bidang MIPA, 19(1), Pp. 7-13. Doi: 10.24036/Eksakta/Vol19-Iss1/83.

[91] Amananti, W. (2017) “Analisis Mikrostruktur Lapisan Tipis Tio2:Zno Yang Dideposisikan Diatas Subtrat Kaca Dengan Metode Spray Coating Untuk Degradasi Limbah Zat Warna", EKSAKTA: Berkala Ilmiah Bidang MIPA, 18(02), Pp. 210-215. Doi: 10.24036/Eksakta/Vol18-Iss02/81.

[92] Nasir, M. (2017) “Pengaruh Waktu High Energy Milling Terhadap Karakteristik Nanokaolin Capkala Asal Kalimantan Barat”, EKSAKTA: Berkala Ilmiah Bidang MIPA, 18(02), Pp. 200-209. Doi: 10.24036/Eksakta/Vol18-Iss02/78.

[93] Mulia, M. (2017) "Isolasi Kumarin Dari Kulit Buah Limau Sundai (Citrus Nobilis Lour)", EKSAKTA: Berkala Ilmiah Bidang MIPA, 18(02), Pp. 137-145. Doi: 10.24036/Eksakta/Vol18-Iss02/70.

[94] Sari, A. (2017) "Potensi Antioksidan Alami Pada Ekstrak Daun Jamblang (Syzigium Cumini (L.) Skeels)”, EKSAKTA: Berkala Ilmiah Bidang MIPA, 18(02), Pp. 107-112. Doi: 10.24036/Eksakta/Vol18-Iss02/61.

[95] Setianto, S. (2017) “Analisa Kuantitatif Campuran Senyawa Oksida Sebagai Dasar Identifikasi Kandungan Bahan Sumber Daya Alam Studi Kasus : Kandungan Mineral Pada Pasir Besi Di Pesisir Pantai Selatan, Jawa Barat”, EKSAKTA: Berkala Ilmiah Bidang MIPA, 18(02), Pp. 173-177. Doi: 10.24036/Eksakta/Vol18-Iss02/74.

[96] Anugraha, Riana Slamet.2014.Pengaruh Penggunaan Ekstrak Buah Nanas Terhadap Tingkat Pemanfaatan Protein Pakan Dan Pertumbuhan Ikan Mas (Cyprinus Carpio). Journal Of Aquaculture Management And Technology. Volume 3, Nomor 4.

[97] Utami, Dhiah Putri, Pudjomartatmo, Pudjomartatmo, Patriadi Nuhriawangsa, Adi Magna. 2017. Manfaat Bromelin Dari Ekstrak Buah Nanas (Ananas Comosus L. 
Merr) Dan Waktu Pemasakan Untuk Meningkatkan Kualitas Daging Itik Afkir. Sains Peternakan: Jurnal Penelitian Ilmu Peternakan. Vol 9, No 2.

[98] Ismanto, A., Basuki, R.2017.Pemanfaatan Ekstrak Buah Nanas Dan Ekstrak Buah Pepaya Sebagai Bahan Pengempuk Daging Ayam Parent Stock Afkir. Jurnal Peternakan Sriwijaya.Vol 6, No 2.

[99] Tasim, Lina, Santoso, I R. S., Rombang, W A. R.2013. Analisis Pemahaman Konsep Reaksi Kimia Melalui Pendekatan Pembelajaran Langsung Pada Siswa Smp Negeri 13 Tidore Kepulauan. Jsme Mipa Unima. Vol 1, No 3.

[100] Ida Bagus Suryadharma, Mahmudi, Istiqomah, Nurul .2019.Pembelajaran Kimia Pada Materi Pokok Laju Reaksi Dengan Pendekatan Konstruktivis Melalui Metode Praktikum Dan Diskusi Untuk Meningkatkan Motivasi Dan Prestasi Belajar Siswa Kelas Xi Man 3 Malang. Jurnal Entropi. Vol4, No 2

[101] Kumaunang, Maureen.2011. Amobilisasi Enzim Bromelin Yang Diisolasi Dari Batang Nanas Dengan Menggunakan Karagenan. Chemistry Progress. Vol 4, No 2

[102] Kumaunang, Maureen, Kamu, Vanda.2011. Aktivitas Enzim Bromelin Dari Ekstrak Kulit Nenas (Anenas Comosus). Jurnal Ilmiah Sains. Vol 11, No 2 (2011): Volume 11 Nomor 2.

[103] Wuryanti, Wuryanti.2006.Amobilisasi Enzim Bromelin Dari Bonggol Nanas Dengan Bahan Pendukung (Support) Karagenan Dari Rumput Laut (Euchema Cottonii). Jurnal Kimia Sains Dan Aplikasi.Vol 9, No 3

[104] Wuryanti, Wuryanti.2004.Isolasi Dan Penentuan Aktivias Spesifik Enzim Bromelin Dari Buah Nanas (Ananas Comosus L.). Jurnal Kimia Sains Dan Aplikasi. Vol 7, No 3 
[105] Nurmala, Linda Wati, Kusrijadi, Ali, Suryatna, Asep.2013. Kajian Penggunaan Amonium Sulfat Pada Pengendapan Enzim Bromelin Dari Batang Nanas (Ananas Comosus (L.) Merr) Sebagai Koagulan Pada Pembuatan Keju Cottage. Jurnal Sains Dan Teknologi Kimia. Vol 4, No 1

[106] M. Adi ,Fatmaraga.Jatmiko, Retnadi Heru.2013. 155 Pemanfaatan Citra Penginderaan Jauh Multitemporal Untuk Kajian Tingkat Bahaya Erosi (Kasus Di Sub DAS Karang Mumus, Kalimantan Timur). Jurnal Bumi Indonesia. Volume 2, Nomor 3

[107] Lekahena, Vanessa, Faridah, Didah Nur, Syarief, Rizal, Peranginangin, R.2014. Karakterisasi Fisikokimia Nanokalsium Hasil Ekstraksi Tulang Ikan Nila Menggunakan Larutan Basa Dan Asam [Physicochemical Characterization Of Nano Calcium From Tilapia Bone Extracted By Alkaline And Acid Solution]. Jurnal Teknologi Dan Industri Pangan. Vol 25, No 1

[108] Fikri, Muhammad Zakiyul, Nurhayati, Tati, Salamah, Ella.2014. Ekstraksi Dan Karakterisasi Parsial Ekstrak Kasar Enzim Katepsin Dari Ikan Patin [Extraction And Partial Characterization Of Crude Enzymes Cathepsin From Catfish]. Jurnal Teknologi Dan Industri Pangan. Vol 25, No 1

[109] Hanum, Tirza.2000.Ekstraksi Dan Stabilitas Zat Pewarna Alam Dari Katul Beras Ketan Hitam (Oryza Sativa Glutinosa)*) Extraction And Stability Of Natural Colorant From Red Glutinous Rice Bran (Oryza Sativa Glutinosa)*). Jurnal Teknologi Dan Industri Pangan. Vol 11, No 1

[110] Hartati, Indah, Yulianto, Mohammad Endy, Handayani, Dwi.2010. Reduksi Dioscorin Dari Umbi Gadung Melalui Ekstraksi Gelombang Mikro. Bio Molekuler, Analis Kesehatan, Keperawatan. Vol 1, No 1 
[111] Rahmawati, Endang Sulistyaningsih, Eka Tarwaca Susila Putra, Hindun.2012. Pengaruh Kadar Nacl Terhadap Hasil Dan Mutu Buah Tomat (Lycopersicum Esculentum Mill.) Vegetalika. Vol 1, No 4

[112] Karina, Sri Trisnowati, Didik Indradewa, Ar Roufi.2012. Pengaruh Macam Dan Kadar Kitosan Terhadap Umur Simpan Dan Mutu Buah Stroberi (Fragraria X Ananassa Duch.). Vegetalika. Vol 1, No 3

[113] Sri Trisnowati, Sri Muhartini, Nurrochman.2013. Pengaruh Pupuk Kalium Klorida Dan Umur Penjarangan Buah Terhadap Hasil Dan Mutu Salak (Salacca Zalacca (Gaertn.) Voss) 'Pondoh Super'. Vegetalika. Vol 2, No 1

[114] Syahputra, Benny.2002. Pemanfaatan Algae Chlorella Pyrenoidosa Untuk Menurunkan Tembaga $(\mathrm{Cu})$ Pada Industri Pelapisan Logam. Jurnal Lingkungan Sultan Agung. Vol 2, No 02

[115] M, Endang Triwahyuni,Yusrin.2008. Penggunaan Metode Kompleksometri Pada Penetapan Kadar Seng Sulfat Dalam Campuran Seng Sulfatdengan Vitamin C. Prosiding Seminar Nasional. Vol 1, No 1

[116] Nugroho, Sri.2011. Karakterisasi Material Refraktori Basa Berbahan Dasar Magnesia (Mgo) Guna Lining Tungku Induksi Pengecoran Baja Di Pt X Klaten. Prosiding Seminar Nasional Sains Dan Teknologi Fakultas Teknik. Vol 1, No 1

[117] Djalil, Asmiyenti Djaliasrin, Nurulita, Nunuk Aries, Margiarto, Adhimi, Yusuf, Emmy E.2006. Penapisan Fitokimia Dan Uji Aktifitas Antibakteri Ekstrak Air Dan Etanol Daun Maja ( Aegle Marmelos Correa). Pharmacy. Vol 4, No 1

[118] Sari, Rodiah Nurbaya, Bandol Utomo, Bagus Sediadi.2007. Uji Coba Alat Penghasil Asap Cair Skala Laboratorium Dengan Bahan Pengasap Serbuk Gergaji 
Kayu Jati Sabrang Atau Sungkai (Peronema Canescens). Jurnal Pascapanen Dan Bioteknologi Kelautan Dan Perikanan. Vol 2, No 1

[119] Januar, Hedi Indra, Wikanta, Thamrin, Chasanah, Ekowati.2007.Analisis Dereplikasi Substansi Bioaktif Fraksi Polar Petrosia Sp. Dari Perairan Kepulauan Seribu. Jurnal Pascapanen Dan Bioteknologi Kelautan Dan Perikanan. Vol 2, No 2

[120] Widyawati, Paini Sri.2002. Pengaruh Parakuat Terhadap Produksi Hidrogen Peroksida Secara Fotokimia Dalam Kloroplas Daun Bayam (Spinacia Oleraceae L.) Jurnal Agritech. Vol 22, No 1

[121] Putri, G. E., Arief, S., Jamarun, N., Gusti, F. R., \& Zainul, R. (2018, December 10). Microstuctural Analysis And Optical Properties Of Nanocrystalline Cerium Oxides Synthesized By Precipitation Method. Https://Doi.Org/10.31227/Osf.Io/Qcz4y

[122] Sularno, S. (2018, August 24). Reaksi Penangkapan Energi Dan Reaksi Fiksasi Karbon Sebagai Istilah Alternatif Pengganti Reaksi Gelap Dan Terang Dalam Proses Fotosintesis. Https://Doi.Org/10.31227/Osf.Io/6crdm

[123] Putri, A. H., Hasibuan, N. H., Mudia, N. E., \& Hawari, F. Y. (2019, April 9). Preparasi Asam Sulfat Skala Industri Di Indonesia. Https://Doi.Org/10.31227/Osf.Io/B2fvh

[124] Anggraini, M. (2018, April 18). Perbandingan Kadar Pori Agregat Campuran AcWc Sebelum Dan Setelah Ekstraksi. Https://Doi.Org/10.31227/Osf.Io/5zqjk

[125] Rahman, H. (2018, May 10). Karakterisasiminyak Kenari Untuk Aplikasi Pangan. Https://Doi.Org/10.31227/Osf.Io/K6cfu 
[126] Zainul, R., Effendi, J., \& M. (2018, December 10). Phototransformation Of Linear Alkylbenzene Sulphonate (Las) Surfactant Using Zno-Cuo Composite Photocatalyst. Https://Doi.Org/10.31227/Osf.Io/Fec28

[127] Pelima, J. N. (2018, August 22). Kandungan Fenolat Dan Aktivitas Antioksidan Ubi Banggai (Dioscorea) Dari Berbagai Varietas. Https://Doi.Org/10.31227/Osf.Io/Vs4xg

[128] 2017, S. N. M. I., \& Hasibuan, R. (2017, November 6). Kajian Kandungan Fitokimia Dari Ekstrak Haramonting (Rhodomytus Tomentosa) Sebagai Obat Herbal. Https://Doi.Org/10.31227/Osf.Io/743yg

[129] Warlinda, Y. A., \& Zainul, R. (2019, February 1). Asam Posfat (H3PO4): Ionic Transformation Of Phosphoric Acid In Aqueous Solution. Https://Doi.Org/10.31227/Osf.Io/86gtm

[130] Alfionita, T., \& Zainul, R. (2019, January 29). Calcium Chloride (Cac12) : Characteristics And Molecular Interaction In Solution. Https://Doi.Org/10.31227/Osf.Io/M37xj

[131] FAJERIANA M, N. (2018, May 29). Simulasi “Greencrop Tracker” Untuk Serapan Hara Tanaman Padi Ladang Dan Kedelai. Https://Doi.Org/10.31227/Osf.Io/9swq8

[132] Warlinda, Y. A., \& Zainul, R. (2019, February 11). Asam Posfat (H3PO4): Ionic Transformation Of Phosphoric Acid In Aqueous Solution. Https://Doi.Org/10.31227/Osf.Io/C76tk

[133] Nurfadilah, K. K., \& Zainul, R. (2019, February 3). Kalium Nitrat (KNO3): Karakteristik Senyawa Dan Transpor Ion. Https://Doi.Org/10.31227/Osf.Io/Dr8ef 
[134] Mektildis, R. (2018, October 12). Formulasi Krim Ekstrak Etanol Kulit Batang Faloak (Sterculia Quadrifida R.Br). Https://Doi.Org/10.31227/Osf.Io/Fujrb

[135] Thressia, M., \& Shinta, D. Y. (2019, January 9). Pemanfaatan Limbah Kulit Melinjo Yang Mempunyai Aktivitas Anti Bakteri Terhadap Bakteri Pathogen Gram Negatif (Escherichia Coli). Https://Doi.Org/10.31227/Osf.Io/Vjcp5

[136] Hidayati, R., \& Zainul, R. (2019, February 1). Studi Termodinamika Transpor Ionik Natrium Klorida Dalam Air Dan Campuran Tertentu. Https://Doi.Org/10.31227/Osf.Io/Yqtku

[137] Febriyanti, T. L. (2019, April 1). Fortifikasi Daun Pepaya Dalam Pakan Ikan Sebagai Upaya Pengembangan Pembudidaya Lele Sangkuriang (Clarias Gariepinus) Di Gorontalo. Https://Doi.Org/10.31227/Osf.Io/Khbd4

[138] 2017, S. N. M. I., \& Hasibuan, R. (2017, November 6). Kajian Kandungan Fitokimia Dari Ekstrak Haramonting (Rhodomytus Tomentosa) Sebagai Obat Herbal. Https://Doi.Org/10.31227/Osf.Io/743yg

[139] Feronika, N. I., \& Zainul, R. (2018, November 19). Kalium Permanganat: Termodinamika Mengenai Transport Ionik Dalam Air. Https://Doi.Org/10.31227/Osf.Io/G6eyk

[140] Asfar, M. (2017, November 8). Perbedaan Kandungan Albumin Ikan Gabus Pada Beberapa Jenis Olahannya. Https://Doi.Org/10.31227/Osf.Io/T8hzm

[141] Rhaska, G., \& Zainul, R. (2019, January 31). Analisis Molekular Dan Transpor Ion Amonium Clorida. Https://Doi.Org/10.31227/Osf.Io/Gwhtq 
[142] Andayani, D. (2017, November 9). Analisis Zat Pewarna Rhodamin B Pada Gula Kapas Merah Yang Dijual Di Kota Mataram Tahun 2013. Https://Doi.Org/10.31227/Osf.Io/H7waq

[143] P. (2018, April 6). Analisis Kandungan Nitrat Dan Phosfat Di Tambak Berbeda Terhadap Pertumbuhan Rumput Laut (Gracilaria Verrucosa (Hudson) Papenfuss). Https://Doi.Org/10.31227/Osf.Io/Xwh6r

[144] Munir, J., JM, J., \& Mulyani, S. (2018, December 5). Potensi Tanaman Padi Yang Dipupuk Dengan Kompos Chromolaena Odorata; Penghasil Gabah Dan Sumber Hijauan Pakan Ternak Penunjang Ketahanan Https://Doi.Org/10.13057/Psnmbi/M020105

[145] Adji, T. N. (2017, October 2). Variasi Spasial-Temporal Hidrogeokimia Dan Sifat Aliran Untuk Karakterisasi Sistem Karst Dinamis Di Sungai Bawah Tanah Bribin, Kabupaten Gunung Kidul, Diy. Https://Doi.Org/10.31227/Osf.Io/X4wyu

[146] Hakimi, A., \& Zainul, R. (2019, January 31). Asam Arsenat (H3aso4) : Analisis Molekular Dan Karakteristik Senyawa. Https://Doi.Org/10.31227/Osf.Io/E486z

[147] Mu'nisa, A., \& Rosi, K. A. (2017, August 29). Pengaruh Pemberian Ekstrak Buah Bakau (Rhizopora Mucronata) Terhadap Penurunan Kadar Gula Darah Mencit (Mus Musculus). Https://Doi.Org/10.31227/Osf.Io/9pkrm

[148] Firdaus, A., \& Zainul, R. (2018, November 6). Sesium Klorida (Cscl) : Transport Ion Dalam Larutan. Https://Doi.Org/10.31227/Osf.Io/Rj6gy

[149] Yuliani, F., \& Zainul, R. (2018, November 13). Analisis Termodinamika Molekul Magnesium Sulphate (Mgso4). Https://Doi.Org/10.31227/Osf.Io/Uxz4y 
[150] Andayani, D. (2017, November 9). Uji Aktivitas Reduksi Stres Oksidatif Ekstrak Etanol Buah Pare (Momordica Charantia, L) Dan Profil Perbaikan Diamater Sel Islet Beta Pankreas Tikus Diabetes Mellitus Yang Diinduksi Aloksan. Https://Doi.Org/10.31227/Osf.Io/Zq5x4

[151] Dwynda, I., \& Zainul, R. (2018, November 19). Boric Acid (H3 (BO3): Recognize The Molecular Interactions In Solutions. Https://Doi.Org/10.31227/Osf.Io/6wead

[152] La Goa, Y. (2018, April 30). Isolasi Dan Karakterisasi Fosfolipase A2 Dari Racun Duri Acanthaster Planci Isolat Perairan Papua. Https://Doi.Org/10.31227/Osf.Io/Mw68s

[153] Shafitri, M., \& Zainul, R. (2019, February 3). Vanadium Pentaoksida (V2O5) : Termodinamika Molecular Dan Interaksi Ion Dalam Larutan. Https://Doi.Org/10.31227/Osf.Io/Jgmvd

[154] Adji, T. N. (2017, October 2). Hubungan Karakter Aliran Dan Sifat Kimia Mataair Petoyan Untuk Karakterisasi Akuifer Karst. Https://Doi.Org/10.31227/Osf.Io/T4yfk

[155] Rahman, H. (2018, May 10). Karakterisasi Minyak Kenari Untuk Aplikasi Pangan. Https://Doi.Org/10.31227/Osf.Io/K6cfu

[156] Ekawandani, N. (2018, July 24). Efektifitas Kompos Daun Menggunakan Em4 Dan Kotoran Sapi. Https://Doi.Org/10.31227/Osf.Io/Pyqaj

[157] Rahman, H. (2018, May 10). Karakterisasiminyak Kenari Untuk Aplikasi Pangan. Https://Doi.Org/10.31227/Osf.Io/K6cfu

[158] Cahyadi, A., Adji, T. N., \& Marfai, M. A. (2017, August 29). Analisis Evolusi Hidrogeokimia Airtanah Di Pulau Koral Pramuka, Kepulauan Seribu. https://doi.org/10.31227/osf.io/dcbup 
[159] Ekawandani, N. (2018, April 2). Pengomposan Sampah Organik (Kubis Dan Kulit Pisang) Dengan Menggunakan EM4. https://doi.org/10.31227/osf.io/3gt26

[160] Putri, A. H., Hasibuan, N. H., mudia, n. e., \& Hawari, F. Y. (2019, April 15). preparasi asam sulfat skala industri di indonesia. https://doi.org/10.31227/osf.io/2fcus

[161] H. (2017, November 8). Pengaruh Pemberian Jerami Padi Denganberbagai Perlakuan (Fisik,Kimia,Biologi Dankombinasi) Terhadapkarkas Domba (Ovisaries)Jantanlokal. https://doi.org/10.31227/osf.io/dsfut

[162] Syafei, N., Hidayat, D., Emilliano, E. and Men, L. (2018) “Analysis Cracking Corrosion on Carbon Steel Pipes API 5L-X65 In Solution $7700 \mathrm{ml}$ Aquades, $250 \mathrm{ml}$ Acetic Acid and $50 \mathrm{ml}$ Ammonia with Gas CO2 and H2S in Saturation Condition", EKSAKTA: Berkala Ilmiah Bidang MIPA, 19(2), pp. 21-31. doi: 10.24036/eksakta/vol19-iss2/138.

[163] Vauzia, V. and Gusmira, E. (2018) “The Response of Jabon Seeds Germination (Anthocephalus cadamba (Roxb.)Miq.) against the Duration of Combustion and Illumination", EKSAKTA: Berkala Ilmiah Bidang MIPA, 19(2), pp. 80-87. doi: 10.24036/eksakta/vol19-iss2/154.

[164] Research Journal, B. A. (2017, November 15). Peranan Unsur Hara Molibdenum Dalam Penambatan Nitrogen. https://doi.org/10.31227/osf.io/8qd5j

[165] Sofyanita, S. and Octaria, Z. (2018) "Fenthion Compound Degradation in the Pesticide Bayleton 500 ec in Sonolysis, Ozonolysis and Sonozolysis with Addition of TiO2-anatase", EKSAKTA: Berkala Ilmiah Bidang MIPA, 19(2), pp. 70-79. doi: 10.24036/eksakta/vol19-iss2/153.

[166] Putri, D., Anika, M. and Wahyuni, W. (2019) "Bioinformatics Study Genes Encoding Enzymes Involved in the Biosynthesis of Carotenoids Line Cassava 
(Manihot esculenta)", EKSAKTA: Berkala Ilmiah Bidang MIPA, 20(1), pp. 10-16. doi: 10.24036/eksakta/vol20-iss1/161.

[167] Masri, Mashuri .2014. Isolasi dan Pengukuran Aktivitas Enzim Bromelin dari Ekstrak Kasar Bonggol Nanas (Ananas comosus) pada Variasi Suhu dan Ph. Jurnal Ilmiah Biologi. Vol 2, No 2. DOI: https://doi.org/10.24252/bio.v2i2.478

[168] s. (2018, April 25). Optimization Ratio Enzim Papain And Bomelin On Process Of Making Solid Organic Fertilizer. https://doi.org/10.31227/osf.io/dh8w9

[169] Ferdhiani, A. A., Lestari, S., \& Proklamasiningsih, E. (2019, February 17). Aktivitas Enzim Peroksidase dan Kadar Klorofil pada Daun Angsana (Pterocarpus indicus) sebagai Peneduh Jalan yang terpapar Timbal. https://doi.org/10.31227/osf.io/86t7h 